\title{
Movements of a Polar Bear from Northern Alaska to Northern Greenland
}

\author{
GEORGE M. DURNER ${ }^{1}$ and STEVEN C. AMSTRUP ${ }^{1}$
}

(Received 21 September 1994; accepted in revised form 14 April 1995)

\begin{abstract}
Using satellite telemetry, we monitored the movements of an adult female polar bear (Ursus maritimus) as she traveled from the Alaskan Beaufort Sea coast to northern Greenland. She is the first polar bear known to depart the Beaufort Sea region for an extended period, and the first polar bear known to move between Alaska and Greenland. This bear traveled for four months across the polar basin and came within $2^{\circ}$ of the North Pole. During the first year following her capture, she traveled 5256 $\mathrm{km}$. Evidence to suggest her use of maternity dens in northern Alaska and in northern Greenland demonstrates the potential for genetic exchange between two widely separate populations of polar bears. The long life spans of polar bears and the rarity of their long-range movements means the significance of interpopulation movement can be assessed only after long-term monitoring of individuals.
\end{abstract}

Key words: polar bear, Ursus maritimus, satellite telemetry, movements, Beaufort Sea, populations, Alaska, Greenland, polar basin

RÉSUMÉ. En utilisant la télémétrie par satellite, on a suivi les déplacements d'une ourse polaire (Ursus maritimus) alors qu'elle allait de la côte de la mer de Beaufort en Alaska au Groenland septentrional. À notre connaissance, elle est la première des ours polaires à avoir quitté la région de la mer de Beaufort pour une longue période, et la première à s'être déplacée entre l'Alaska et le Groenland. Cette ourse a traversé le bassin polaire durant quatre mois et s'est approchée à moins de $2^{\circ}$ du pôle Nord. Au cours de la première année suivant sa capture, elle a parcouru $5256 \mathrm{~km}$. Des preuves suggérant qu'elle a utilisé les tanières de mise bas dans l'Alaska septentrional et dans le Groenland septentrional démontrent le potentiel d'échanges génétiques existant entre deux populations d'ours polaires séparées par une grande distance. La longévité importante des ours polaires et la rareté des déplacements lointains signifient que les déplacements entre diverses populations ne peuvent être évalués qu'après une surveillance à long terme des individus.

Mots clés: ours polaire, Ursus maritimus, télémétrie par satellite, déplacements, mer de Beaufort, populations, Alaska, Groenland, bassin polaire

Traduit pour la revue Arctic par Nésida Loyer.

\section{INTRODUCTION}

Polar bears inhabit most ice-covered seas of the northern hemisphere (Amstrup and DeMaster, 1988; DeMaster and Stirling, 1981). Despite habitat contiguity, the world population of polar bears comprises at least six subpopulations (DeMaster and Stirling, 1981). Subpopulations of polar bears are suggested by mark-and-recapture studies (Lentfer, 1983), VHF and UHF radio telemetry (Amstrup and Gardner, 1994), and morphometrics (Manning, 1971; Wilson, 1976). While polar bears that occupy the Beaufort Sea adjacent to Alaska and the mainland coast of Canada are believed to be part of a relatively discrete subpopulation (Amstrup, 1995), there is a potential for gene flow between adjacent regions. Bears first captured in the Chukchi Sea of Alaska occasionally traveled into the Beaufort Sea, but returned to the Chukchi Sea after several months (Garner et al., 1990). Approximately 25\% of satellite observations of polar bears first captured in the Beaufort Sea occurred in the northeastern Chukchi Sea (Amstrup, 1995). Movements east of Cape Bathurst, Canada, are less frequent: only $12 \%$ of satellite observations occurred east of $127^{\circ}$ (Amstrup, 1995). In contrast, no movement of polar bears from Alaska to the Canadian High Arctic or Greenland has previously been observed (Lentfer, 1983). However, as with any natural system, exceptions to previous findings can be expected. This note describes the first known movement of a female polar bear from the Alaskan Beaufort Sea to northern Greenland.

\section{METHODS}

On 22 May 1992, we captured a female polar bear and her two accompanying cubs of the year (COY) within sight of the Prudhoe Bay oil fields (capture location: $70^{\circ} 18^{\prime} \mathrm{N}, 147^{\circ} 36^{\prime} \mathrm{W}$ ). This family group was one of hundreds captured in a multiyear study of polar bears in northern Alaska. The adult was immobilized with an injection of $1000 \mathrm{mg}$ of tiletamine HCL and zolazepam HCL (Telazol®, Warner-Lambert Co.) using a projectile syringe fired from a helicopter (Stirling et al.,

${ }^{1}$ National Biological Service, Alaska Science Center, 1011 East Tudor Road, Anchorage, Alaska 99503, U.S.A.

(C) The Arctic Institute of North America 
1989). Each COY received an injection of $100 \mathrm{mg}$ of Telazol that was administered by hand. A unique identification number was tattooed on the inside upper lip of each bear, and tags with an identical number were attached to both ears of each bear. The adult was fitted with a Platform Transmitter Terminal (PTT) radio collar (Telonics, Inc., Mesa, Arizona, U.S.A.), which allowed relocation by satellite (Fancy et al., 1988). PTTs provide the animal's location (mean error $=954 \mathrm{~m}$ [Harris et al., 1990]), temperature of the collar, and three indices of activity (60-second, hourly, long-term) (Amstrup, 1995). The PTT duty cycle was two days on, five days off. Distances between consecutive records were calculated according to Buchanek and Bergin (1976). Reported distances within time intervals represent the sum of distances calculated for consecutive locations within those intervals. Tooth section cementum annuli counts indicated that the adult was 11 years old when captured. All three bears were recovering from the Telazol immobilization at the time of our departure ( 75 minutes after injection). No further visual observations were made.

\section{RESULTS}

Location records were collected until 19 December 1993, after which decreasing PTT signal strength precluded location calculation. However, sensor records were obtained until 2 April 1994. The total distance traveled from capture location to 19 December 1993 was $7162 \mathrm{~km}$ (distance between observations $[\bar{x} \pm \mathrm{SE}]: 110.2 \pm 19.6 \mathrm{~km} ; n=65)$. Total duration of location data included 576 days (interval between observations $[\bar{x} \pm \mathrm{SE}]: 8.9 \pm 2.1$ days; $n=65$ ).

After release, the adult left the Prudhoe Bay area and traveled north (Fig. 1). She reached her northernmost location on 9 August 1992 at $88^{\circ} 0^{\prime} \mathrm{N}, 98^{\circ} 12^{\prime} \mathrm{W}$. With the exception of the period from 5 July to 11 July, all travel was generally northward (between $320^{\circ}$ and $73^{\circ}$ ) until 9 August 1992. By 9 August, she had traveled $2686 \mathrm{~km}$ (distance between observations $[\bar{x} \pm \mathrm{SE}]: 141.4 \pm 50.5 \mathrm{~km} ; n=19$ ), with a mean rate of travel of $34.0 \mathrm{~km} /$ day (range: 5.2 to $89.5 \mathrm{~km} /$ day; interval between observations $[\bar{x} \pm \mathrm{SE}]: 4.2 \pm 0.8$ days; $n=19$ ).

After 9 August, the adult traveled southeast until 6 September 1992 to $85^{\circ} 48^{\prime} \mathrm{N}, 21^{\circ} 48^{\prime} \mathrm{E}$ longitude. Then she traveled southwest, reaching $82^{\circ} 55^{\prime} \mathrm{N}, 18^{\circ} 52^{\prime} \mathrm{W}$ on 10 October 1992 , and remained in the McKinley Sea vicinity until at least 22 November 1992. At that time she had traveled $4190 \mathrm{~km}$. Because of weak radio signals, no location data and few sensor records were received from 22 November 1992 until 27 March 1993. Collar temperature increased $24^{\circ} \mathrm{C}$, and sensors indicated a decline in activity of $93 \%$, from early October to late December, suggesting that this bear entered a den on the sea ice at approximately $83^{\circ} 31^{\prime} \mathrm{N}, 22^{\circ} 51^{\prime} \mathrm{W}$. The resumption of location data, decreased collar temperature and increased activity indicated that she exited her den by 27 March 1993 at $84^{\circ} 15^{\prime} \mathrm{N}, 24^{\circ} 35^{\prime} \mathrm{W}$. This was $84 \mathrm{~km}$ from her location on 22 November 1992.

The adult traveled southwest along the Greenland coast and arrived at Kane Basin $\left(79^{\circ} 27^{\prime} \mathrm{N}, 66^{\circ} 55^{\prime} \mathrm{W}\right)$ on 24 April

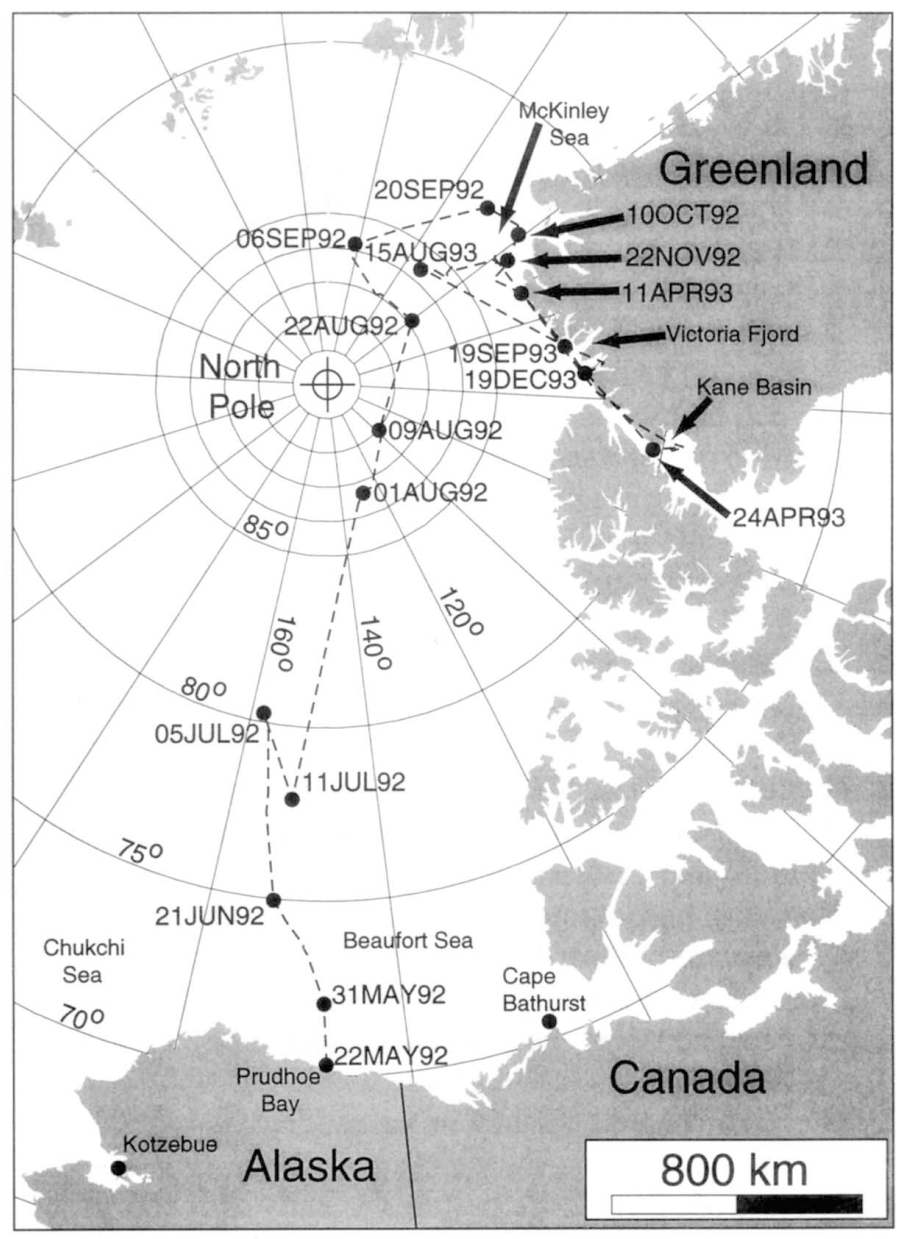

FIG. 1. Travel route and location dates for an adult female polar bear following capture in northern Alaska, 22 May 1992. Not all location dates are included.

1993 (Fig. 1). She remained there until 22 May 1993, at which point she had traveled a total of $5256 \mathrm{~km}$ since capture. By 17 July 1993, she had returned to the region of the previous winter's den $\left(83^{\circ} 52^{\prime} \mathrm{N}, 20^{\circ} 31^{\prime} \mathrm{W}\right)$, where she remained until late August 1993. Her next location fix did not occur until 19 September 1993 near the mouth of Victoria Fjord $\left(82^{\circ} 57^{\prime} \mathrm{N}\right.$, $47^{\circ} 49^{\prime} \mathrm{W}$ ), where she remained until at least 19 December 1993. From early October to late December, collar temperature increased $17^{\circ} \mathrm{C}$ and activity declined $82 \%$, suggesting that she entered another den. Continued high collar temperature and low activity during that period suggest that she remained in her den until early April 1994. No further data were available because of failing PTT batteries.

\section{DISCUSSION}

This female polar bear displayed extraordinary movements during the first year following her capture and release. PTTs have provided 140 bear-years of location data on adult female polar bears captured in the Beaufort Sea. However, this is the first polar bear known to move from Alaska to Greenland. Her most northern location equaled that in previous reports of polar bears at $88^{\circ} \mathrm{N}$ (Stefansson, 1921; Papanin, 
1939). Her rate of travel during May-August, 1992 ( $\bar{x}=34$ $\mathrm{km} /$ day), surpassed that of single bears and bears with yearlings $(\bar{x}=13 \mathrm{~km} /$ day, $n=2007)$ during those months (Amstrup and Durner, unpubl. data). Despite the four-month period that the adult was in a den, the total distance she traveled during the year following capture $(5256 \mathrm{~km})$ was greater than the annual distance reported for non-denning polar bears in the Beaufort Sea $(\bar{x}=3436 \mathrm{~km}$; range: 2114 5281; $n=37$ ) (Amstrup, 1995). Distance moved (84 km) during den tenure may be accounted for by her movements just prior to den entrance and following den exit during PTT off times, and by sea ice drift (Amstrup and Gardner, 1994). Her movements are unusual because of the type of ice habitat that she traveled through. Female bears with COYs usually occupy fast ice, floe edge, and near-shore drifting ice (Amstrup and DeMaster, 1988). Examination of satellite locations with passive microwave imagery of sea ice indicate bears from the Chukchi Sea rarely used permanent pack ice during summer (Arthur et al., 1993). Yet, between late June and September 1992, this bear traveled across permanent and relatively stable multiyear pack ice.

We found no obvious health problems with these bears. Body mass was compared to that of other bears of similar age and reproductive status that were captured between 1 May and 11 May; however, we do not have other data for late May. The adult body mass $(159 \mathrm{~kg})$ was within the range of other female polar bears captured in early May $(\bar{x}=170.5 \mathrm{~kg}$, range: $141-204, n=6$ ). Each COY had a body mass of $14 \mathrm{~kg}$. Body mass of other COYs captured in early May was generally higher $(\bar{x}=19.2 \mathrm{~kg}$, range: $13-27, n=14)$. Considering that COYs are growing during May, a body mass of $14 \mathrm{~kg}$ in late May could have been too low for the COYs to survive. Approximately $35 \%$ of polar bears die before their second year of life (Amstrup and Durner, 1995).

Analysis of location data generated by PTT-equipped polar bears suggests that the bounds of the Beaufort Sea population extend from Cape Bathurst, Canada $\left(127^{\circ} \mathrm{W}\right)$, to Kotzebue, Alaska $\left(162^{\circ} \mathrm{W}\right)$, and northward to approximately 300 miles from the mainland coast (Amstrup, 1995). Movements outside of these bounds is uncommon and seasonal, as polar bears typically return to the central Beaufort Sea during summer months (Amstrup, 1995). Polar bears can show a high degree of fidelity to geographic areas (Derocher and Stirling, 1990). Pregnant polar bears will return to the general vicinity of their previous maternity den (Ramsay and Stirling, 1990; Amstrup and Gardner, 1994), which may also be the bear's own place of birth (Derocher and Stirling, 1990). Thus, the bear in this report displayed very unusual movements. It is not possible to determine the origin of this bear. The movement data obtained from October 1992 to December 1993 and evidence of den use indicated that this bear was well established in northern Greenland. However, her appearance in Alaska is significant from a reproductive standpoint. The presence of two cubs of the year indicated that she had given birth near the Alaskan/Canadian Beaufort Sea coast during the winter of 1991/1992.
Polar bears may occupy snow dens either to conserve energy when weather is harsh and prey is scarce (Messier et al., 1994) or to provide a suitable environment for parturition (Amstrup and Gardner, 1994; Messier et al., 1994). Messier et al. (1994) reported that den tenures of $<150$ days' duration may represent shelter use by nonpregnant polar bears. This bear may have entered a den in order to avoid unsuitable hunting conditions. Amstrup and Gardner (1994) reported that the duration of den use by polar bears known to be pregnant was 81-183 days. The duration of den use by the bear in this report during 1992/93 (125 days) and 1993/94 (approximately 100 days) falls within this range. If den use was for parturition, it would mean that she lost the cubs from spring 1992, bred in the Beaufort Sea shortly thereafter, lost those cubs as well, and therefore bred again in the spring of 1993. Her long-distance movements also suggest the loss of the COYs captured in 1992. Female bears with COYs do not travel as far as single bears or those with older young (Ramsay and Andriashek, 1986; Amstrup, 1995).

This bear demonstrates the importance of long-term studies of polar bear ecology. Although several populations of polar bears have been identified, gene flow among geographically distant populations may occur (Cronin et al., 1991). Because movements among populations by polar bears are infrequent, genetic exchange is expected to be low. Verifying the level of genetic exchange by movements of polar bears is difficult, however, because our data include only a short period $(\bar{x}=2.6$ years, range: $<1-20.2$; combined mark-recapture and telemetry data) of each individual's life. Because polar bears may potentially live 25 years or more, long-term data from individuals is important for understanding population integrity.

\section{ACKNOWLEDGEMENTS}

Principal funding for this work was provided by the National Biological Service/U.S. Fish and Wildlife Service (U.S. Department of the Interior), the Minerals Management Service, ARCO Alaska Inc., BP Exploration Inc., and AMOCO Inc. We thank Steven Arthur, James Finn, Leslie HollandBartels, Malcolm Ramsay, Nicki Stevens, and an anonymous reviewer for reviewing this manuscript. Use of corporate names, brand names and trade marks does not constitute endorsement by the United States Government.

\section{REFERENCES}

AMSTRUP, S.C. 1995. Movements, distribution, and population dynamics of polar bears in the Beaufort Sea. Unpublished Ph.D. thesis, University of Alaska, Fairbanks, Alaska, U.S.A.

AMSTRUP, S.C., and DeMASTER, D.P. 1988. Polar bear Ursus maritimus. In: Lentfer, J.W., ed. Selected marine mammals of Alaska: Species accounts with research and management recommendations. Washington, D.C.: Marine Mammal Commission. 39-56. 
AMSTRUP, S.C., and DURNER, G.M. 1995. Survival rates of radio-collared adult polar bears and their dependent young. Canadian Journal of Zoology 73:1312-1322.

AMSTRUP, S.C., and GARDNER, C. 1994. Polar bear maternity denning in the Beaufort Sea. Journal of Wildlife Management $58: 1-10$.

ARTHUR, S.M., GARNER, G.W., and RUDNICKY, T.C. 1993. Limitations of GIS and remote sensing for considering spatial and temporal change of habitat use by polar bears. Fourth Annual United States Fish and Wildlife Service GIS Workshop, Lafayette, Louisiana, 3-6 May 1993.

BUCHANEK, J., and BERGIN, E. 1976. Piloting/navigation with the pocket calculator. Blue Ridge Summit, Pennsylvania: Tab Books. 406 p.

CRONIN, M.A., AMSTRUP, S.C., GARNER, G.W., and VYSE, E.R. 1991. Interspecific and intraspecific mitochondrial DNA variation in North American bears (Ursus). Canadian Journal of Zoology 69:2985-2992.

DeMASTER, D., and STIRLING, I. 1981. Ursus maritimus. Mammalian Species, No. 145.7 p.

DEROCHER, A.E., and STIRLING, I. 1990. Distribution of polar bears (Ursus maritimus) during the ice-free period in western Hudson Bay. Canadian Journal of Zoology 68:1395-1403.

FANCY, S.C., PANK, L.F., DOUGLAS, D.C., CURBY, C.H., GARNER, G.W., AMSTRUP, S.C., and REGELIN, W.L. 1988. Satellite telemetry: A new tool for wildlife research and management. Resource Publication 172. Washington, D.C.: United States Department of the Interior, Fish and Wildlfe Service.

GARNER, G.W., KNICK, S.T., and DOUGLAS, D.C. 1990. Seasonal movements of adult female polar bears in the Bering and Chukchi Seas. International Conference on Bear Research and Management 8:219-226.

HARRIS, R.B., FANCY, S.G., DOUGLAS, D.C., GARNER, G.W., AMSTRUP, S.C., McCABE, T.R., and PANK, L.F. 1990. Tracking wildlife by satellite: Current systems and performance. Fish and Wildlife Technical Report 30. Washington, D.C.: United States Department of the Interior, Fish and Wildlfe Service.

LENTFER, J.W. 1983. Alaska polar bear movements from mark and recovery. Arctic 36:282-288.

MANNING, T.H. 1971. Geographical variation in the polar bear Ursus maritimus Phipps. Ottawa: Canadian Wildlife Service Report Series, No. 13.

MESSIER, F., TAYLOR, M.K., and RAMSAY, M.A. 1994. Denning ecology of polar bears in the Canadian Arctic Archipelago. Journal of Mammalogy 75:420-430.

PAPANIN, I.D. 1939. Life on an ice-floe. Translated from the Russian by Fanny Smithan. London: Hutchinson. 240 p.

RAMSAY, M.A., and ANDRIASHEK, D.S. 1986. Long distance route orientation of female polar bears (Ursus maritimus) in spring. Journal of the Zoological Society of London 208:63-72.

RAMSAY, M.A., and STIRLING, I. 1990. Fidelity of female polar bears to winter den sites. Journal of Mammalogy 71:233-236.

STEFANSSON, V. 1921. The friendly Arctic. New York: Macmillan. STIRLING, I., SPENCER, C., and ANDRIASHEK, D. 1989. Immobilization of polar bears (Ursus maritimus) with telazol in the Canadian Arctic. Journal of Wildlife Diseases 25:159-168.

WILSON, D.E. 1976. Cranial variation in polar bears. International Conference on Bear Research and Management. IUCN Publications New Series 40. 447-453. 